\title{
Late Cenozoic Himalayan foreland basin: Sedimentologic attributes
}

Scientist (Retd.), Wadia Institute of Himalayan Geology, 33 GMS Road, Dehra Dun - 248001, Uttarakhand, INDIA

e-mail:drrohtashgpt@gmail.com

(Received : 5/11/2018; Revised accepted : 24/07/2019)

https://doi.org/10.18814/epiiugs/2020/020026

Late Cenozoic fluvial stratigraphic records of the Himalayan foreland basin- the Siwalik Group between Rivers Ganga and Ravi were studied and reviewed to understand the responses of allogenic forcing at variable timeframe. The Siwalik succession represents an upward stratigraphic coarsening sequence which was initiated $\sim 13$ Ma and terminated and deformed by the Himalayan Frontal Thrust (HFT) at around 0.2 Ma. Fluvial architecture, composition and paleoflow patterns exhibits patial and temporal variations and characteristics of a large river that evolved around $10 \mathrm{Ma}$ with southward propagating mountain front with large gravelly alluvial fans evolving after 5 Main the proximity of Main Boundary Thrust (MBT). Influx of boulder- to pebblesized clasts indicatesmajor surface uplift at around 5 Ma all along the Himalaya. This uplift is more widespread and responsible for the generation of much of the modern drainage system. The fluvial architecture reveals variation in temporal and spatial deposition style at million-year scale in response to variable hinterland topography, tectonics and climate. However, direct climatic signatures are not evident, although stable isotopic studies suggest variability at million-year scale, which was overwhelmed by tectonics.

\section{Introduction}

The Himalayan foreland basin (HFB) was formed in response to thrust loading in Himalaya during the Cenozoic. During the early stage the basin was influenced by marine processes that gradually changed into fully fluvial-driven continental processes at around 44 Ma (Bhatia and Bhargava, 2006, Bera et al., 2008; Sangode et al., 2010) or at around 28 Ma with an unconformity between Subathu and Dagshai Formations (Najman et al., 2004; Najman, 2006; Jain et al., 2009). In the Indian part the HFB is extensively studied to understand the variability in depositional setting (Tandon, 1976, 1991; Kumar and Tandon, 1985; Burbank et al., 1996; Kumar et al., 2003a; 2004a,b; 2011; Goswami and Deopa, 2018 and references therein), marine to fluvial transition (Srivastava and Casshyap, 1983; Singh, 1978; Najman; 2006; Bera et al., 2008; Kumar et al; 2008 and references therein), biostratigraphy, faunal evolution and migration route (Pilgrim., 1913; Colbert., 1935; Agrawal et al., 1993; Nanda and Sehgal, 1993; Nanda, 2002; 2013; 2015; Basu., 2004; Patnaik, 2013; Gilbert et al., 2017; Nanda et al., 2018 and references therein), magnetostratigraphy (Azzaroli, and Naponeone, 1982; Johnson et al., 1983; Tandon et al., 1984; Ranga Rao, 1993; Ranga Rao et al., 1995, Sangode et al., 1996, 1999, 2003; Chirouze et al., 2012; Sangode, 2014; Govin et al., 2018 and references therein), thrusting event (e.g. Meigs et al., 1995; Kumar et al., 1999; 2002; 2003a,b; 2011; Ghosh and Kumar, 2000; Jain et al., 2000; Gavillot et al., 2018), exhumation history (e.g. White et al., 2002; Jain et al., 2009; Adlakha et al., 2013; Chirouze et al., 2013; Lang et al., 2016; Gavillot et al., 2018 and References therein), and Indian monsoon and vegetation changes (e.g. Sanyal, et al., 2004; 2010; Ghosh et al., 2004; Vögeli et al., 2017; Ghosh et al., 2018; Kotla et al., 2018 and references therein). Sedimentation pattern and fluvial architecture of late Cenozoic basin fill stratigraphy of the HFB marked temporal and spatial variability (Tandon, 1991; Willis 1993; Burbank et al., 1996; Kumar et al., 2011) in terms of channels and body geometry, lateral and vertical architecture and its relationship with flood plain fines. It also evaluated the role of allogenic signals (such as stratigraphy base level change during active and quiescent phase and climate effect). Moreover, topographic variation along the strike of hinterland of HFB controlled the precipitation pattern and probably caused architecture variability. A decade of geodynamic modelling and physiographic evidences inferred linkage of topography and precipitation (e.g. Beaumont et al., 2001; Montgomery and Brandon, 2002; Burbank et al., 2003; Wobus et al., 2005; Bookhagen and Burbank, 2006; 2010; Theide et al., 2017 and references therein). Earlier studies inferred that almost present-day topography of Dhauladhar Range in the Kangra sub-basin was established before $10 \mathrm{Ma}$ (Sinha et al., 2007; Deeken et al., 2011; Theide et al., 1017), whereas it evolved after $5 \mathrm{Ma}$ in Dehradun subbasin (Kumar et al., 2003a). Heavy precipitation, rapid erosion and the syn- and post-tectonic activity are therefore interrelated and can greatly alter the sediment load, grain-size pattern, locus of sedimentation and hence the overall fluvial architecture. 
The present review is a compilation of late Cenozoic deposits in the northwestern part of HFB which includes Dehradun, Subathu and Kangra sub-basins between Rivers Ganga and Ravi (Fig. 1A and B). These sub-basins show marked variation in fluvial architecture, channel/overbank ratio, paleoflow pattern, clasts and minerals composition, depositional setting and hinterland topography. Objectives of this reviewis to provide (1) causative factors controlling fluvial architecture between River Ganga in the southeast and Ravi in the northwest, and (2) response of hinterland topography, tectonic and climate on the evolution of drainage system.

\section{Geology and study area}

The Paleocene-Eocene Himalayan succession provides evidences towards the withdrawal of the Subathu and Zanskar seas (Raiverman and Raman, 1971; Sahni et al., 1983) in response to collision of Indian and Eurasian plates around 55 Ma (van Hinsbergen, 2012; Najman et al., 2010 and references therein). Subsequent thrusting and crustal loading in the Himalaya resulted in development of peripheral HFB in the south and foundations of the well-developed fluvial, fauna and floral records of the world. Petro-mineralogy data reveal that the Murree Formation received detritus from low-grade metamorphic sequences whereas underlying Subathu predominantly comprises sedimentary provenance (Kumar et al., 2008; Singh et al., 2009; Bera et al., 2008). Therefore, earlier fluvial deposits of the HFB is represented by the Murree and its equivalent (Balakot, DagshaiKasauli, Dharamshala formation), leading to uplift of the Himalaya.

The HFB succession is exposed along the southern front of the Himalayan orogen, trends WNW to ESE and confined by the Main Boundary Thrust (MBT) to the north and Himalayan Frontal Thrust (HFT) to the south (Fig.1B). The Siwaliks are thrust over modern flat-lying alluvium of Indo-Gangetic foredeep toward south of the HFT (Karunakaran and Ranga Rao, 1976), whereas PrecambrianCambrian Lesser Himalaya is thrust along the MBT. The HFB is divided into a number of sub-basins such as Kangra, Subathu, Dehra Dun by several basement highs and ridges, demarcated by transverse lineaments ((Fig. 1C; Raiverman et al., 1983). Stratigraphy of the Siwalik succession in the entire length of the basin is divided into three Subgroup - Lower, Middle and Upper Siwalik. (e.g., Prakash et al., 1980, Tandon, 1991; Burbank et al., 1996; Cina et al., 2009; Kumar et al, 2011; Chirouze et al., 2012; Lang and Huntington, 2014; Coutand et al., 2016; Govin et al., 2018). In the Sub-Himalaya, the Siwalik succession is folded into anticlines and synclines. In the Dehra Dun and Kangra re-entrants, the synclinal folded Siwaliks is overlain by post-Siwalik Quaternary deposits.

The present study focuses on the late Cenozoic succession in the HFB exposed between Rivers Ganga and Ravi, NW Himalaya.

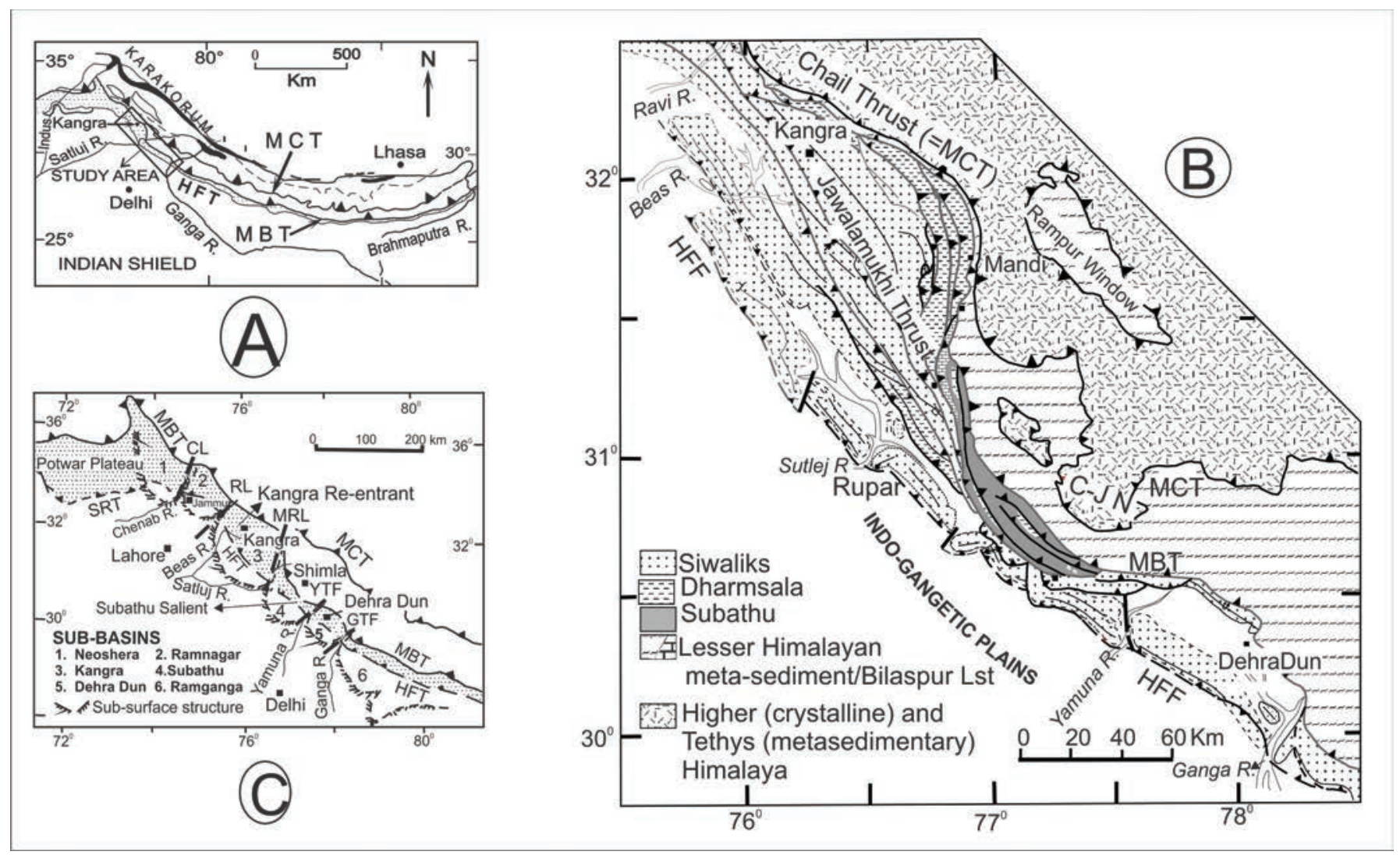

Figure 1. A. Geological map of the Himalayan range showing the extent of Himalayan (Siwalik) foreland basin between the Indus and Brahmaputra river; B. Simplified geological map of the hinterland of Himalayan foreland basin between Ravi and Ganga Rivers (modified Karunakaran and Ranga Rao, 1976; Raiverman, 2002); C. Geological map of the northwestern part of Himalayan foreland basin showing various sub-basin (after Raivermanet al., 1983).

MCT = Main Central thrust; MBT = Main Boundary Thrust; HFF = Himalayan Frontal Fault; SRT = Salt Range Thrust; CL = Chanab lineament; $R L=$ Ravi lineament; $M R L=$ Manali-Rupar lineament; YTF = Yamuna Tear Fault; GTF = Ganga Tear Fault. 


\section{Siwalik Group}

\section{Sedimentation Pattern}

The onset of Siwalik sedimentation is not truly understood due to insufficient information for the reconstruction of the basin geometry, tectonic setting and litho-contact relations during the initiation of foreland sedimentation in the Himalaya. However, sedimentation history in combination with bio- and magnetostratigraphy has made a greater contribution in deciphering the evolution of Outer and Lesser Himalaya during Siwalik time. Detailed description, review and account of previous work in this context is given by Karunakaran and Ranga Rao (1976), Parkash et al. (1980), Tandon (1991), Burbank et al. (1996), Najman (2006) and Kumar et al. (2011).The Siwalik succession shows stratigraphic coarsening up and records deposition from low-gradient sinuous to high gradient braided rivers in the form of alluvial fans along the Himalayan mountain front, as the thrust front propagated southward with migration of depositional lobe at the rate of $19 \pm 5 \mathrm{~mm} / \mathrm{yr}$ (Mugnier and Huyghe, 2006). The Lower Siwalik (LS) is mudstone-dominated and consists of alternating finegrained sandstones and siltstones; the Middle Siwalik (MS) is dominated by fine-medium- to coarse-grained sandstone and up section increase of conglomerates, whereas the Upper Siwalik (US) is mainly composed of conglomerates interceded with sandstones and some siltstones especially in the re-entrant. The latter is divided into the Tatrot, Pinjor and Boulder Conglomerate formations in the salient. The channel body connectness in the LS is $<50 \%$, $>50 \%$ throughout the MS and US succession in the re-entrant, whereas the US has marked variability in the salient. Willis (1993) inferred variation in the proportion of channel bodies at formations level, for example the Chinji Formation (prior to $11 \mathrm{Ma}$ ) has $<50 \%$ and Nagri Formation (between 11 and $9 \mathrm{Ma}$ ) has $>50 \%$ in the Potwar Plateau. This scheme is not applicable in the Indian part of the HFB. For example, Dehra Dun sub-basin (DSB) shows $>90 \%$ channel body proportion between 9 and $5 \mathrm{Ma}$; Subathu sub-basin (SSB) shows $>70 \%$ between 6 and 5 $\mathrm{Ma}$, whereas in the KSB between 11 and $5 \mathrm{Ma}$, the channel body proportion shows rapid changes over short stratigraphic ( $0.5 \mathrm{Ma})$ intervals (Fig. 2).

\section{Sedimentary succession between Rivers Ganga and Ravi}

\section{Dehra Dun Sub-basin (DSB)}

Based on ten parallel litho-sections, lithostratigraphy of the DSB is established that comprises the MS (sandstone-dominated) and US (conglomerate-dominated) Subgroup (Kumar, 1993). A detailed sedimentologic analysis of the MS Subgroup (between 9 and 5.23 Ma, based on magnetostratigraphy, Sandode et al., 1999) is described in Kumar and Nanda (1989), Kumar (1993), Kumar and Ghosh (1994) and Kumar et al. (2003a, b; 2004a), whereas the US is covered by Kumar and Ghosh, (1991) and Kumar et al. (2003a). The MS succession of the DSB (Fig. 2) represents a multi-storey sandstone complex (900-1200 m thick), with facies variation from sandstonemudstone (300-450 m thick) to sandstone (900-1200 m thick) and finally to sandstone-mudstone-conglomerate (100-250 m thick). The grey sandstones are fine-medium to coarse-grained that occur as multistorey units with sheet geometry. Individual stories vary in thickness from 0.5 to more than $3 \mathrm{~m}$, each underlain by a major erosional surface, which extends laterally for hundreds of meters. The erosional surfaces are locally irregular, but generally planar, although some show relief of the order of $1 \mathrm{~m}$. Individual stories within the multistorey sandstone are recognized by presence of intraand extra-formational clasts along the base of each storey, differences in paleocurrent azimuths (in order of $\pm 90^{\circ}$ ), and the orientation of erosional surface. Trough cross-stratification and parallel laminations are the dominant internal structures in these sandstones. The paleoflow data, obtained through trough cross-stratification, shows S, SE and SW vector modes. At outcrop level, the data sets show clustering around the mean paleoflow direction. However, temporally and spatially there is high variability of the order of $\pm 90^{\circ}$.

The MS succession is conformably overlain by a transitional contact of the US Subgroup. The lower part of the latter is represented by conglomerate, sandstone and mudstone facies. These facies typically form upward fining 3-25 m thick cycles, with erosional bases. The conglomerate facies gradually increases up-section and is marked by laterally and vertically amalgamated sheets of gravel beds. These constitute dominantly clasts of quartzite (70-85\%), both from Inner and Outer Lesser-Himalaya, with minor argillite (5-10\%; including slate and phyllite), limestone (5-20\%), granitoid-gneiss (1-3\%), and mafic volcanic rocks (<1\%; Kumar and Ghosh, 1991). The paleoflow data obtained mainly from clast imbrication suggest a southwestward flowing paleo-drainage.

\section{Subathu sub-basin (SSB)}

This sub-basin falls in the salient between the Kangra and Dehra Dun re-entrants separated by Satluj and Yamuna Rivers (Fig. 1A). It dominantly comprises US succession having three formations-Tatrot, Pinjor and Bounder Conglomerate, with LS and MS. The MS is exposed along southeastern part (Fig. 2) whereas the LS (Nahan Formation; Sen, 1981) is overriding the MS and US along the Nahan Thrust. The sedimentology is based on four measured sections at Haripur (Kumar et al. 1999); Khetpurali, Moginand and Ghaggar (Kumar and Tandon, 1985; Kumaravel et al. 2005). Magnetostratigraphic study (Tandon et al., 1984; Sangode et al., 1996; Kumaravel et al., 2005) suggests that the exposed succession is deposited between $\sim 6$ and $\sim 0.5$ Ma south of the Nahan Thrust.

In the southeastern parts, the MS, deposited between $\sim 6$ and 5.5 Ma, pinches out towards northwest, and consists of thickly bedded (>40 m) multistorey grey sandstone with minor mudstones displaying trough cross-stratification. The intervening massive mudstones are brown to grey and contain calcrete nodules. Immature paleosols and bioturbation features are commonly observed in the mudstone. Paleoflow data obtained through trough cross-stratification shows southeasterly trend. After $\sim 5.5 \mathrm{Ma}$, deposition of US was initiated as the Tatrot, Pinjor and Boulder Conglomerate formations. In the Tatrot Formation ( 5.5-2.58 Ma) three types of sandstone bodies are observed: (i) major grey sheet bodies (W/D $>100$ ), (ii) minor grey sheet bodies (W/D $>15<100$ ), and (iii) ribbon bodies, both grey and buff (W/D <15). The ribbon sandstone bodies are associated with higher proportion of overbank deposits. A distinct conglomerate body is observed at 2.6 Ma at the Tatrot-Pinjor formational boundary; these bodies substantially increase up-section in abundance. In the Pinjor Formation, the minor grey sheet sandstone is accompanied by preTertiary clast-bearing conglomerates (Fig.2). These conglomerates are stratified, imbricated and are composed of subangular to 


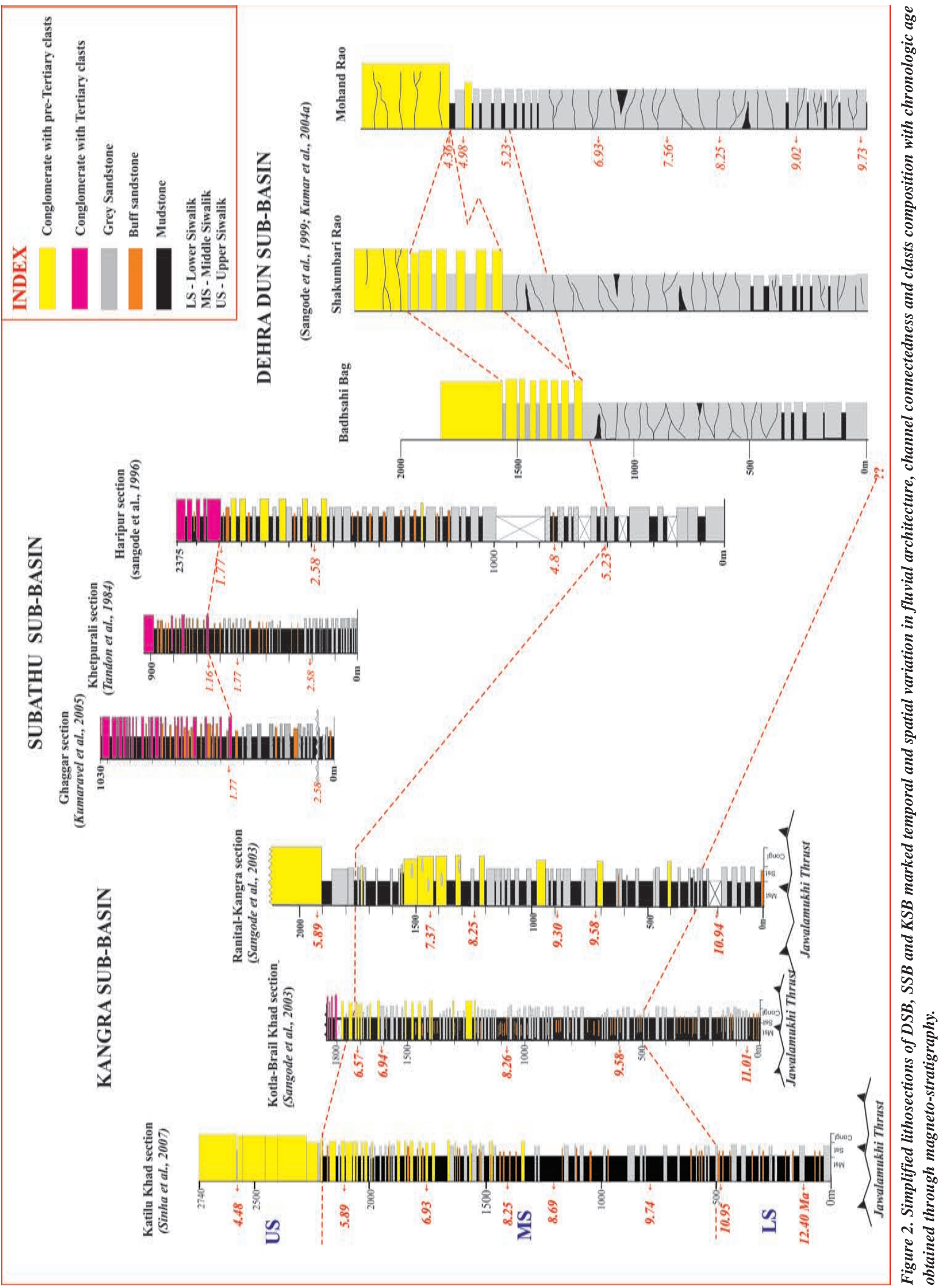


subrounded clasts of quartzite with minor limestone, phyllite, slate, chert, granitoid, and rare basic igneous rocks similar to clasts composition of DSB (Kumar et al., 2003a). Clast size ranges from 10 to $15 \mathrm{~cm}$, with the largest clasts of $20 \mathrm{~cm}$ in diameter. The paleoflow directions of grey and buff sandstones are almost perpendicular to each other and show SW (mean 226 ) and SE (mean $159^{\circ}$ ) trend, respectively (Kumar et al., 1999).

At the contact between the Pinjor and the Boulder Conglomerate formations ( $\sim 1.77 \mathrm{Ma}$ ), the conglomerate clast composition changes from the Lesser Himalayan-derived quartzite to Sub-Himalayanderived (Tertiary) sandstone (Fig.2). The conglomerate beds are 1-6 $\mathrm{m}$ thick in the basal part of the Boulder Conglomerate Formation. These conglomerates are stratified, imbricated and composed of subrounded to subangular clasts which are embedded in buff sandy muddy matrix, interbedded with buff sandstones and abundant mudstones (overbank/channel deposit ratio $>5$ ). The size of the conglomerate bodies, clast size (up to $50 \mathrm{~cm}$ ) as well as angularity increases up section. The conglomerates have abundant muddy matrix and are weakly imbricated. Paleoflow trends, obtained through trough cross-stratification and clasts imbrication, are marked dominantly toward S-SE.

In the north-westernparts of the area, thickness of the Tatrot Formation decreases and exhibits similar characteristics as those in the southeastern part (see Kumar and Tandon, 1985), except that there is an absence of pre-Tertiary clasts with SE paleoflow trend. Up section, the Pinjor Formation comprises only buff sandstone of sheet and ribbon geometry with southerly paleoflow direction; it gradually passes upwards in to Bounder Conglomerate Formation. Conglomerates of this formation have similar characteristics as in the southeastern part, however, these consist only of Tertiary clasts. Paleoflow direction, obtained from clast imbrication, show S-SW trend with high azimuthal variability. However, the Boulder Conglomerate Formation have a time transgressive lower contact ranging from 1.77 to $1.16 \mathrm{Ma}$ (Fig. 2). The formation represents alluvial fan sedimentation, which was initiated at $\sim 1.77 \mathrm{Ma}$ in the southeastern (Haripur) and northwestern Ghaggar River sections, whereas its timing is at $\sim 1.16$ Ma between at Khetpurali and Moginand sections (Tandon et al., 1984; Kumaravel et al., 2005; Kumar et al., 2007; 2011).

\section{Kangra Sub-Basin (KSB)}

The Siwalik succession in the KSB is divided into the northern and southern belt by the Jawalamukhi Thrust (JMT; Fig. 1B). All the three Subgroups LS, MS and US are well exposed in the northern belt, whereas only the MS and US are exposed in the southern belt. Magnetostratigraphic studies by Johnson et al. (1983), Meigs et al. (1995), Brozovic and Burbank (2000), Sangode et al. (2003) and Sinha et al. (2005) suggest that the succession exposed, north of the Jawalamukhi Thrust, were deposited between $\sim 13$ and 3.5 Ma, though upper age appears to be ambiguous.

Sedimentology of KSB is based on eight litho-stratigraphic sections: two sections in the northwestern part at Katilu Khad and Nagrota (Sinha et al.,2005, 2007) and the remaining sections in the southeastern part at Kotla-Brail and Ranital-Kangra (Sangode et al., 2003; Kumar et al., 2004b), Kangra and Nalad Khad (Brozovic and Burbank, 2000), Jawalamukhi (Meigs et al., 1995) and Haritalyangar section (Johnson et al., 1983). The entire area exhibits remarkable variation in fluvial architecture and paleoflow pattern.

\section{Southeastern Area}

Marked temporal variations in sedimentation pattern (Fig. 2) are observed in $\sim 3 \mathrm{~km}$ thick succession (cumulative thickness) encompassing upper part of LS, MS and US Subgroups. These sediments essentially represent cycles of alternating channel and overbank facies. Proportion of channel bodies shows temporally increasing trends along Ranital-Kangra (RK) section (Fig. 2). The LS consists of interbedded dark grey fine-grained sandstone and purple brown mudstone; the latter exhibits pedogenesis with calcrete, bioturbation and rootlets. The sandstones are thin (0.8 to $2 \mathrm{~m}$ ) with ribbon geometry (W/D $=<15$ ) and some beds display trough-cross stratification and ripple marks. Mean paleoflow, obtained by trough cross-stratification, is toward south (Mean-182 ${ }^{\circ}$ ) with minor modes toward southeast (Kumar et al., 2004b). The MS exhibits variations in fluvial architecture and colour of sandstone. The sandstone represents sheet geometry with low mudstone content. Variation in channel body proportion is of the order of 200 to $300 \mathrm{~m}$ stratigraphic interval (Fig. 2). Within the individual fluvial cycle, the percentage of overbank facies (includes crevasse splay and levee deposit) varies from 20 to 80 percent. Single to compound paleosol-bound overbank sequences are common. The paleosol shows grey and green mottling and possesses calcareous and ferruginous concretions. The conglomerate facies in the MS (between $~ 8.7$ and 7.0 Ma), are well stratified, imbricated and fining upward beds of 1 to $2 \mathrm{~m}$ thickness, comprising of rounded to well-rounded clasts of quartzite, basics, granite/gneiss and sandstone. Initially these conglomerates show coarsening up succession up to $\sim 7.2 \mathrm{Ma}$, followed by fining upward succession. The conglomerates within MS are observed at 10.0 Ma in the Nalad Khad section (Brozovic and Burbank, 2000), about $40 \mathrm{~km}$ NE from the RK section with southwestward paleoflow direction and thus prograde southwestwards with decrease in bed thickness and clast size, and simultaneous increase in matrix proportion. Further west, percentage of coarse-grained facies decreases with increased mudstone as observed in the Kotla-Brail section (Fig. 2). However, cycle thickness is almost similar to the RK section, where channel body proportion is $50 \%$ that increases in the southeastern side up to 80 percent and decrease in the northwestern part in Kotla-Brail Khad section to only 36\%. Paleoflow pattern of the MS marks major change from S-SE (LS) to SW with mean azimuth toward $239^{\circ}$, parallel to the basin axis.

Thick accumulation of conglomerate of the US succession ( 2000m thick) is observed after 6 Ma with sandstone and rarely mudstone beds in the lower part and thickly bedded conglomerates in the upper section with increasing clasts size in the all measured sections. The conglomerates are poorly to moderately sorted, with subrounded to rounded clasts, crudely stratified and transverse imbrication clast fabrics; the beds show sheet geometry. Clasts are matrix-supported but clastssupported pebble, cobble and boulder-conglomerates are also present. Clast size ranges from 10 to $40 \mathrm{~cm}$, reaching to a maximum of $50 \mathrm{~cm}$ in the up-section. These conglomerates are truly polymictic and include crystalline white (40-60\%) and pink quartzite (10-15\%), limestone (15-20\%), granite/gneiss (5-10\%), sandstone (Tertiary, 14-18\%), basic volcanic (1-4\%) and others (4-10\%). The paleoflow trend is towards SW with mean $250^{\circ}$ and a high variability of the order $\pm 40^{\circ}$ (Kumar et al., 2004b). 


\section{Northwestern Area}

Compared to the southeastern area, the associated facies are different all together in the northwestern area (Fig.2). North of the JMT, the Katilu Khad and Nagrota sections have similar characteristics. Sedimentologic studies in the area were made by Tandon and Rangaraj (1979) and Sinha et al. (2005, 2007, 2008). The Siwalik succession in this area was deposited between $\sim 12.7$ and 2Ma (upper age ambiguous), and shows varying percentage of channel and overbank cycle (Fig. 2). Based on lithostratigraphy, it is difficult to recognise the LS and MS, as both have similar lithofacies association. Multistorey, vertical and lateral amalgamated mediumto fine-grained, fining upward, 7 to 18 mthick, grey sandstone occurs between 12.7 and $\sim 6$ Ma with up section decreasing trend. Internally, the channel sandstone shows erosional surfaces, trough and planar cross-stratification, ripple marks and rarely parallel lamination. These sandstones pass upward into overbank facies with sharp contacts which include paleosol-bound mudstone, levee and crevasse splay, fine-grained buff ribbon sandstone and lacustrine deposits with varying thickness within individual cycle from 34 to $176 \mathrm{~m}$. The buff sandstones are fine-grained with ribbon geometry bound by mudstone and are massive, but some beds display trough cross-stratification and ripple marks.The mudstones are in general purple and at places variegated colour and have several mature to immature paleosol horizons as both isolated and compound profiles. At $\sim 8.39 \mathrm{Ma}$ (Fig. 2), distinct conglomerate bed is observed comprising 2-10 cm clasts of granite/ gneiss, mylonite gneiss, greenish, grey and white quartzite, schist, limestone and sandstone. The average clast-size, proportion and frequency of conglomerate beds gradually increase with decrease grey sandstone up section and finally disappear at the contact of US at $\sim 6 \mathrm{Ma}$. The paleoflow data shows high variability with mean azimuth direction $98^{\circ}$ for the grey sandstones, whereas $210^{\circ}$ for buff sandstones, almost perpendicular to each other (Sinha et al., 2007).

After $\sim 5.7 \mathrm{Ma}, \sim 1500 \mathrm{~m}$ thick, laterally amalgamated and multi-storied conglomerates of the US are massive to crudely stratified and at places trough cross-stratified. Further up section, thickly bedded, amalgamated sheet conglomerates are present. Lenticular body of medium- to coarse-grained sand lenses ( $~ 50-60 \mathrm{~cm}$ thick) and mudstones (20-40 cm thick) are also present. They have similar characteristics as in northeastern part, except that these differ in paleoflow direction toward S-SW with azimuthal mean $230^{\circ}$ and clast composition. These conglomerates comprise greenish, grey and white quartzite (12-35\%), granite/ gneiss (10-27\%), mylonite gneiss (1-5\%), schist (1-5\%), siliciclastic (20-35\%), slate (1-3\%) and limestone (2-15\%) and sandstone (10$40 \%$ ). The paleoflow pattern obtained through clast imbrication reveal S-SW with azimuthal mean $230^{\circ}$ and high variance in order of $\pm 60^{\circ}$.

Aforesaid data reveal variation in fluvial architecture, paleoflow pattern and clast composition in the SE and NW part of the Kangra sub-basin. The MS, although deposited by opposite flowing axial river having similar architecture, shows dominancy of S-SW trending transverse stream deposits in northwestern area. However, during the US time, alluvial fan progrades toward SW along basin axis in the southeastern area, whereas it is S-SW-directed in the northwestern area. Granite clasts and percentage feldspar are high in the northwest as compare to southeast.

\section{Discussion}

\section{Depositional environment}

The Siwalik succession between the Rivers Ganga and Ravi, representing alternate re-entrant and salient along the strike, shows distinct variation in fluvial architecture, composition and paleoflow pattern, although all the sub-basins represent stratigraphic coarsening upwards. Sedimentation pattern broadly reveals that the depositional setting varied at sub-basin scale during late Cenozoic in the HFB. The LS is present in the KSB and SSB on the hanging wall of the Nahan Thrust. However, Johnson et al. (1983) correlated Nahan Formation with MS in the Haritalyangar area of the KSB. Associated facies and paleoflow data suggest its deposition by S-SE flowing high sinuosity streams with broad floodplain and pedogenic alteration due to sub aerial exposure (Meigs et al., 1995; Burbank et al., 1996; Kumar et al., 2004b).

The MS of the KSB exhibits high variability as compare to DSB and also differ in the SE and NW part although they have similar hinterland and high relief. In the SE area, the MS of KSB in the RK section deposits by confined, gravelly braided stream flowing toward SW direction with well-defined floodplains. Thick conglomerate facies deposited in the form of alluvial fan, between 10 and 7.2 Ma, is observed in the extreme NE part of the basin along Nalad Khad section which prograde towards SW. This suggests that development of the MS gravelly alluvial fan was initiated around 10 Ma at Nalad Khad area, progrades south-westward along basin axis and tapered toward southwest in RK section. This resulted into a gradual change from unconfined to confined channel in the span of $40 \mathrm{~km}$ (without balancing). Further downstream, in the Kotla-Brail section (Fig. 2), gravel progradation was delayed and inferred depositional pattern exhibits marked transition from meandering to braided stream with well-developed floodplains (Kumar et al., 2011). On the other hand,the MS were deposited by the southeast-flowing braided stream in the area. Although sedimentation in both the areas took place by axial river flowing opposite to each other, time-equivalent transverse piedmont stream (TPS) deposited sediments in the sheet flood environment (Sinha et al., 2007), and are dominant in the northwestern part that interfingered with axial river deposits. Vertical stacking of axial and TPS deposits indicates that both the stream types have changed their position several times between 12 and 6 Ma (Sinha et al., 2007). These two time-equivalent fluvial systems interfinger with each other, but display distinct facies. Presence of conglomerate in the TPS suggests high energy conditions and gradient that gradually increased up section resulting in migration of the axial drainage toward farther edge of the basin. This further suggests that the TPS deposits gradually convert into alluvial fan toward basin margin and transition from TPS to alluvial fan was responsible for totally dislodging axial river deposits. On the other hand, the MS of DSB (9.0-5.23 Ma) shows radial paleoflow pattern and deposited by sheet floods environment in the form of a southward prograding sandy alluvial fan, deposited by southeasterly flowing axial braided river in the SSB. Both in the KSB and DSB, the US Subgroup have $>2000 \mathrm{~m}$ thick conglomerate in the vicinity of basin margin, having high degree of paleoflow variability, rapid variation in clast size (laterally and vertically), non-erosive lower contact and coarsening upwards sequences; all these suggest deposition by unconfined channels in the distal to medial alluvial fan (Kumar and Ghosh., 1991; Kumar et al, 2004a; 2011; Sinha et al., 2007). Although these conglomerates 
were deposited in the form of alluvial fans, these have different depositional settings and progradation directions. In the northeastern part of the KBS, fans prograde along the basin axis in the SW direction, whereas these were transverse to mountain in the DSB and northwestern part of KSB. The depositional setting of sedimentary succession of the DSB is marked by two overlapping sandy (MS) and gravelly (US) alluvial fans (Kumar and Ghosh, 1994). The SSB has varied history of facies associations and fluvial architecture. Between 5.23 to 1.77 Ma facies associations (Tatrot and Pinjor Formations) show interfingering of grey, sheet and buff, ribbon sandstone bodies. The grey sheet sandstones associated with quartzite clast-bearing conglomerate after 2.6 Ma were deposited by southwestward flowing transverse trunk stream. In contrast, buff ribbon sandstone, bounded by overbank deposits without lateral migration features, reveal deposition by south-eastward flowing laterally fixed channel forming the tributary of trunk stream (Kumar et al 1999, 2003a, b). After 1.77 Ma and up-section, quartzite clast-bearing conglomerate is replaced by sandstone clasts-bearing conglomerate, which was deposited in the form of proximal to distal alluvial fan setting, prograding into S-SE direction and dislodged completely the southeasterly flowing trunk drainage from this basin.

\section{Clast composition variability}

Truly polymictic clast composition varied at sub-basin scale and was dependent on the hinterland lithology. The eastern part of the KSB comprises dominantly quartzite clasts (both white and pink), limestone, granite/gneiss ( $<5 \%$ ), sandstone (Tertiary), basic volcanic and low-grade metamorphics and reveals complex provenance, having rock types from the hanging wall of both the MBT and Chail Thrust (MCT). Some clasts (up to 18\%) have been cannibalized from the foreland basin sediments (Meigs et al., 1995; Raiverman, 2002; Kumar et al., 2004b). In contrast, in the northeastern area, percentage of granite/gneiss increases up to $30 \%$ with decrease of quartzite (12$35 \%$ ) and other clast types, and suggest major source from the Chail Nappe and Dauladhar granite (Sinha et al., 2008). The DSB has dominant quartzite with subordinate amount of limestone, shale, siltstone, sandstone, phyllite, schist, slate, granite-gneiss and basic rocks. Among the quartzite clasts, $60-70 \%$ are from the Outer Lesser Himalaya and the 10-15\% represent the Inner Lesser Himalaya. Upsection and laterally toward SW, quartzite clasts increase from $70 \%$ to $85 \%$, with decrease in limestone and granitoid clasts (Kumar and Ghosh, 1991). In contrast, the SSB has dominant quartzite clasts similar to the DSB up to $1.77 \mathrm{Ma}$ and up section, these are replace by the Tertiary clast (Kumar et al., 1999; 2003a).

\section{Tectonic, Climatic and topographic affects}

The Siwalik succession between Rivers Ganga and Ravi shows marked variation in fluvial architecture, composition, paleoflow pattern and depositional setting. Such variations in the basin fill stratigraphy can be gained by past environmental changes as well as changes in hinterland tectonics, topography, composition and climate (Bridge, 2003). The foreland stratigraphy was largely controlled by thrust sheet evolution that controlled the sedimentation (e.g. Chapman and DeCelles, 2015). It is also affected by regional isostatic uplift by exhumation and uplift associated with advancing thrust wedge or retrograde migration of the forebulge (Quinlan and Beaumont, 1984; Flemings and Jordan, 1990; Sinclair et al., 1991). The exhumation- orography-climate relation is significant during the late Cenozoic evolution of HFB and exhibits strong relationship between tectonic uplift and climatic variation. Broadly, varied fluvial architecture, paleoflow direction and composition between Rivers Ravi and Ganga reveal following aspect: (i) fluvial architecture shows contrast variation at the transition from LS to MS at $10 \mathrm{Ma}$ from ribbon to thick multistorey sandstone with change in paleoflow direction; (ii) thick conglomerate appears at $\sim 6$ to $5 \mathrm{Ma}$, with variation in SSB; (iii) drainage re-organisation in the southeastern part of KSB at $10 \mathrm{Ma}$ and at $5 \mathrm{Ma}$ at DSB; (iv) axial drainage dislodged at $5.5 \mathrm{Ma}$ in the NW part of the KSB and SSB, and (5) southwestward flowing trunk stream totally dislodge after $1.77 \mathrm{Ma}$ in the SSB. Apart from this, basin-scale variation is observed in the SSB at 4.8 Ma, and exhibits partitioning of the basin with peak activity at $1.77 \mathrm{Ma}$ (Kumar et al., 1999, 2002, 2003a, b; Ghosh et al., 2003; Suresh et al., 2004). Similarly, the DSB also records re-activation of the MCT at around 7.5 Ma (Sandoge et al., 1999; Ghosh and Kumar, 2000; Kumar et al., 2004a). The two major events at 10 and $5 \mathrm{Ma}$ are further discussed, since these mark major changes in the HFB and are regionally significant especially in its NW sector.

The 10 Ma event is represented by creation of a big river system with broad catchment area in the Higher Himalayan region and enhanced net sediment accumulation rate. During this time mass accumulation rate in the Ganga Basin and Bay of Bengal drastically increased (Schumm and Rea, 1995; Métivier et al., 1999, Clift, 2006). Similarly, at 5 Ma sudden influx of conglomerate facies was interpreted as the reseult of major uplift and creation of new mountain front. This uplift is widespread throughout the Himalaya and is responsible for the modern drainage system in the foreland (Abbasi and Friend, 2000; Kumar et al., 2003b). However, in the salient, conglomerate flux appeared after 1.77 Ma which was related to partition of the foreland basin and creation of piedmont system (Kumar et al., 1999, 2002).

Apart from tectonic controls on basin fill, climate has also exerted an influence on the overall distribution of grain size and rate of sediment supply to the basin. Reconstructions of weathering in East Asia show that faster erosion correlates with more humid, warm climates in the early-middle Miocene, changing to less erosive, drier climates after 14 Ma when Antarctic glaciation began (Clift, 2006). Mineralogical data suggest major source was the Higher Himalayan Crystalline around 10 Ma (Najman et al., 2006; Sinha et al., 2008). During this time, the Bengal basin also received higher input from Higher Himalayan Crystalline. This suggests topography of Higher Himalaya forms an orographic barrier for high precipitation and hence enhance exhumation. The topographic gradient of the HFB is highly variable for re-entrant and salient. The topography in the KSB rises abruptly from the low-lying Gangetic Plain in the south to a series of peaks exceeding $>4000 \mathrm{~m}$ in the Chamba Nappe to the north before 10 Ma (Deeken et al., 2011; Sinha et al., 2005; Theide et al., 1917), whereas these were $\sim 2000 \mathrm{~m}$ along the MBT at $\geq 5 \mathrm{Ma}$ in the DSB (Kumar et al., 2003a) and gentler in the SSB (Raiverman, 2002). Therefore, orographic-controlled precipitation in the re-entrant is high as compare to salient. The fluvial architecture around 10 and $5 \mathrm{Ma}$ suggests gradual increase in river size and its discharge as a result of orographic-controlled increased precipitation of both in the DSB and KSB, having source from the Himalayan crystalline and Lesser Himalaya. Carbon and oxygen isotope ratios of soil carbonate nodules and carbon isotope ratio of associated organic matter also indicated that monsoon intensified around 10 to $6 \mathrm{Ma}$ with changes in vegetation 


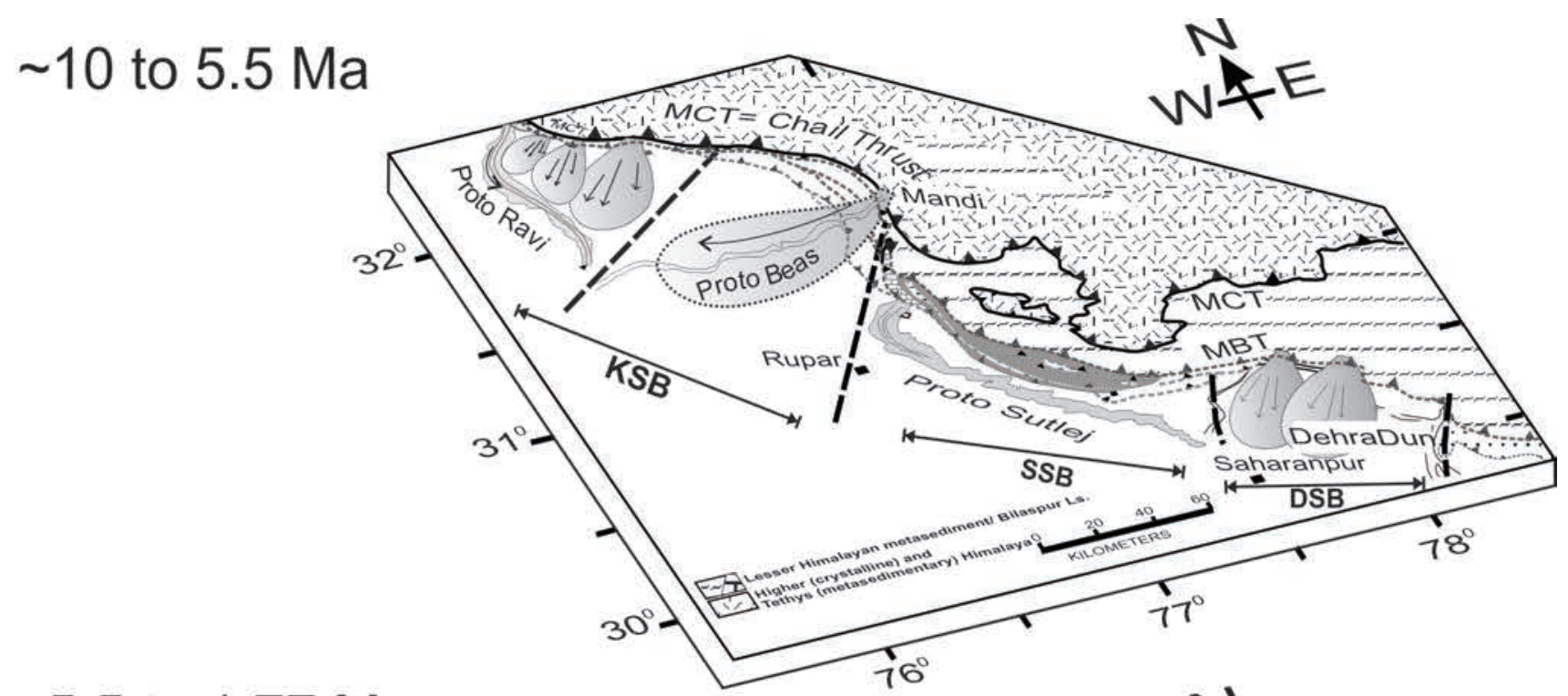

\section{$\sim 5.5$ to $1.77 \mathrm{Ma}$}

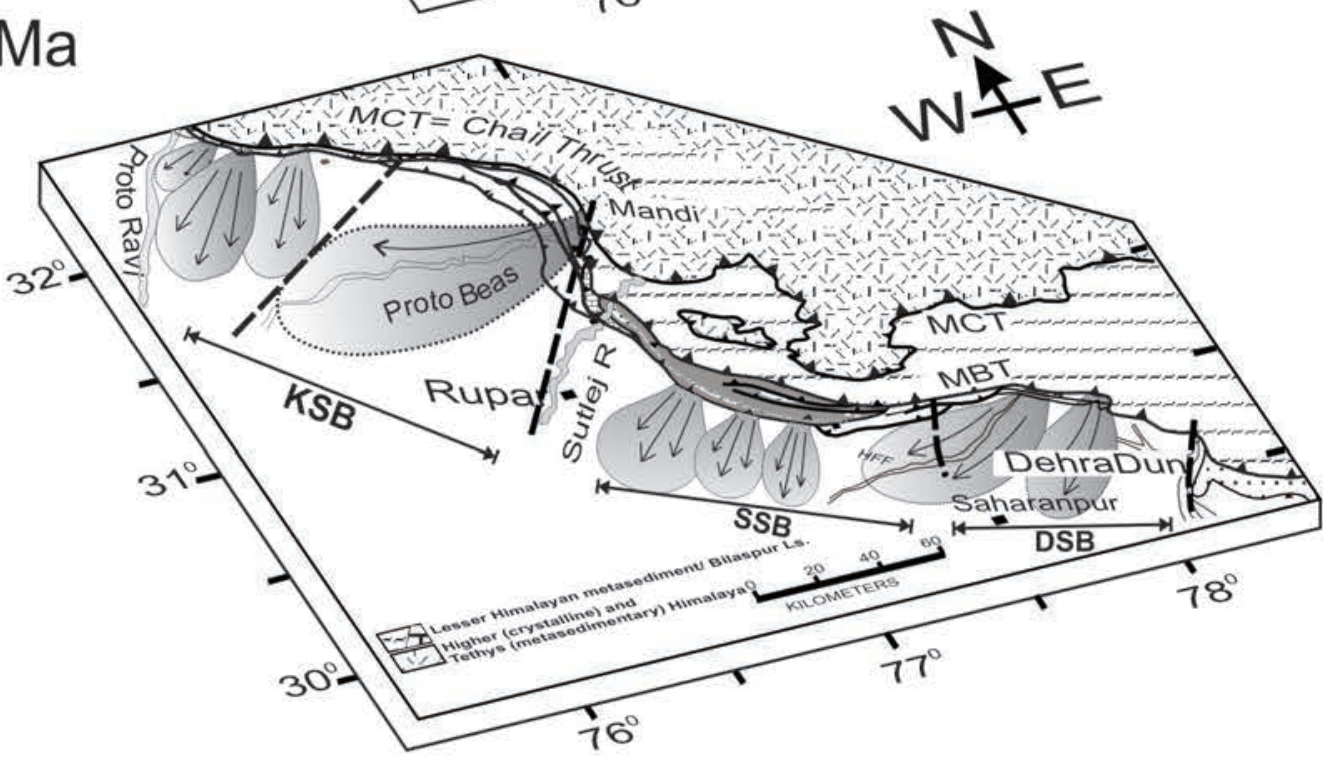

\subsection{7 to $0.25 \mathrm{Ma}$}

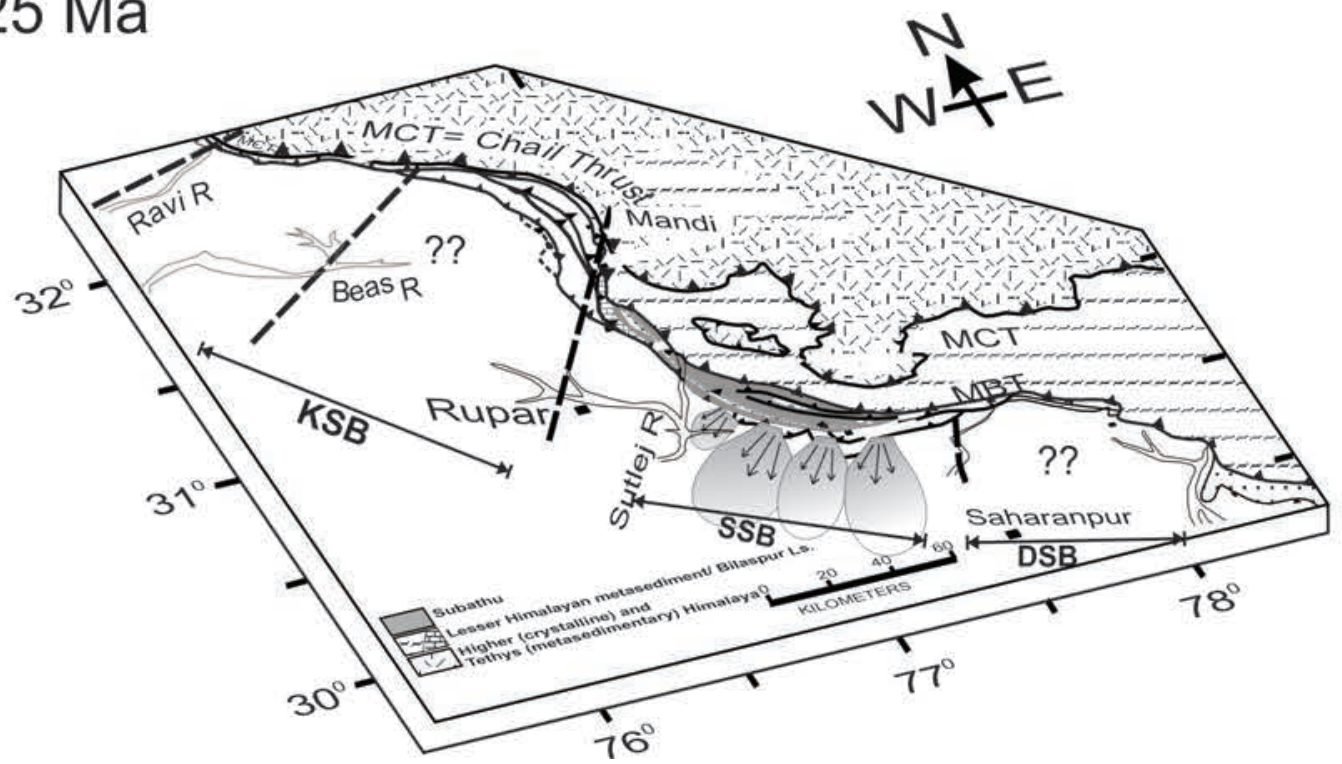

Figure 3. Schematic depositional model illustrating chronologic-wise modifications and spatial relationship of fluvial system between River Ravi and Ganga (displacement of various transverse lineaments are adjusted to give the prefaulting scenario). MCT=Main Central Thrust; MBT= Main Boundary Thrust. (Adopted from Kumar et al., 2011). 
from C3 to C4 grasses types around 6 Ma (Sanyal et al., 2004; Sinha et al., 2009). Kumar et al. (2011) proposed a conceptual tectonoclimatic controlled depositional model showing temporal and spatial variation in depositional realm (Fig. 3).

\section{Conclusion}

In the peripheral Himalayan Foreland Basin, the Late Cenozoic Siwalik Group deposits were initiated at 13Ma and terminate at around 0.2Ma. This basin received detritus from the rising Himalaya with southward propagating mountain front. Sedimentary succession marked spatial and temporal variation in fluvial architecture, channel/ overbank ratio, paleoflow direction, clasts and mineralogical composition, depositional environment that were governed by both allogenic, autogenic and autogenic processes as well as hinterland topographic variation. Rapidly increasing topographic gradient in the HFB was responsible for contrasting fluvial architecture between the Rivers Ganga and Ravi. In the low relief-low gradient landscape, the erosional rate is slower as compared to high relief landscape. This contrasting architecture also favoured the variability in climate and tectonic forcing which influenced landscape-scale of erosion rate.

\section{Acknowledgment}

This review is based on the effort of a team of scientists (myself; SK Ghosh-petrography; S Sangode-magnetostratigraphy and rock magnetism; Subojit Sinha) of the Wadia Institute of Himalayan Geology. I duly acknowledge them and the then Director. I am also grateful to the two reviewers and Prof. AK Jain for improving this review article.

\section{References}

Abbasi, I.A., and Friend, P.F, 2000, Exotic conglomerate of the Neogene Siwalik succession and their implications for the tectonic and topographic evolution of the Western Himalaya. In: Khan, M. A., Treloar, P. J., Searle M. P., and. Jan,M. Q. (Eds.), Tectonics of the Nanga Parbat Syntaxis and the Western Himalaya, Geological Society of London, Special Publication, 170, pp. 455466.

Adlakha, V., Patel, R.C., Lal, N., Metha, Y.P., Jain, A.K., and Kumar, A., 2013, Tectonics and climate interplay: Exhumation pattern of the Dhauladhar Range, Northwest Himalaya. Current Science, v. 104(11), pp. 1551-1559.

Agarwal, R.P., Nanda, A.C., Prasad, D.N., and Dey, B.K., 1993, Geology and biostratigraphy of the Upper Siwalik of Samba area, Jammu foothills. Journal of Himalayan Geology, v. 4 (2),pp. 227236.

Azzaroli, A., and Naponeone, G.,1982, Magnetostratigraphic investigation of the upper Siwalik Near Pinjor, India. Review of Italian Paleontology, v. 87, pp. 739-762.

Basu, P.K., 2004, Siwalik mammals of the Jammu Sub-Himalaya, India: An appraisal oftheir diversity and habitats. Quaternary International, v. 117, pp. 105-118.

Beaumont, C., Jamieson, R.A., Nguyen, M.H., and Lee, B., 2001, Himalayan tectonics explained by extrusion of a low-viscosity crustal channel coupled to focused surface denudation. Nature, v. 414, pp. 738-742.

Bera, M.K., Sarkar, A. Chakraborty, P.P., Loyal, R.S., and Sanyal P., 2008, Marine to continental transition in Himalayan foreland.
Geological Society of America Bulletin, v. 120, pp. 1214-1232. Bhatia, S.B., and Bhargava, O.N, 2006, Biochronological continuity of the Paleogene sediments of the Himalayan Foreland Basin: paleontological and other evidences. Journal. Asian Earth Science, v. 26, pp. 477-487.

Brozovic, N., and Burbank, D.W., 2000, Dynamic fluvial systems and gravel progradation in the Himalayan foreland. Geological Society of America Bulletin, v. 112, pp. 394-412.

Bookhagen, B., and Burbank, D.W., 2006, Topography, relief, and TRMM-derived rainfall variations along the Himalaya. Geophysical Research Letters, v. 33, L08405. https://doi.org/ 10.1029/2006GL026037.

Bookhagen, B., and Burbank, D.W., 2010, Toward a complete Himalayan hydrological budget: Spatiotemporal distribution of snowmelt and rainfall and their impact on river discharge. Journal of Geophysical Research, v. 115, F03019. https://doi.org/10.1029/ 2009JF001426.

Bridge, J.S., 1993, The interaction between channel geometry, water flows, sediment transport and deposition in braided rivers. In: Best, J.L., and Bristow, C.S. (Eds.), Braided Rivers, Geological Society of London, Special Publication, 75, pp. 13-71.

Burbank, D.W., Blythe, A.E., Putkonen, J., Pratt-Sitaula, B., Gabet, E., Oskin, M., Barros, A., and Ojha, T. P., 2003, Decoupling of erosion and precipitation in the Himalayas. Nature, v.426, pp. 652-655.

Burbank, D.W., Beck, R.A.,and Mulder, T., 1996, The Himalayan foreland basin. In: Yin, A., and Harrison, T.M. (Eds.) Tectonic Evolution of Asia, Cambridge Univ. Press, USA, pp. 149-188.

Chapman, J.B., and DeCelles, P.G., 2015, Foreland basin stratigraphic control on thrust belt evolution. Geology, v. 43,pp. 579-582.

Chirouze, F., Dupont-Nivet, G., Huyghe, P., van der Beek, P., Chakraborti, T., Bernet, M., and Erens, V., 2012, Magnetostratigraphy of the Neogene Siwalik Group in the far eastern Himalaya: Kameng section, Arunachal Pradesh, India. Journal of Asian Earth Sciences, v. 44, pp. 117-135.

Chirouze, F., Huyghe, P., van der Beek, P., Chauvel, C., Chakraborty, T., Dupont- Nivet, G., and Bernet, M., 2013, Tectonics, exhumation, and drainage evolutionof the eastern Himalaya since 13 Ma from detrital geochemistry and thermochronology, Kameng River section, Arunachal Pradesh. Geological Society of America Bulletin, v. 125, pp. 523-538.

Cina, S.E., Yin, A., Grove, M., Dubey, C.S., Shukla, D.P., Lovera, O.M., Kelty, T.K., Gehrels, G.E., and Foster, D.A., 2009, Gangdese arc detritus within the eastern Himalayan Neogene foreland basin: Implications for the Neogene evolution of the Yalu-Brahmaputra River system. Earth and Planetary Science Letters, v. 285, pp. 150-162.

Clift, P.D., 2006, Controls on the erosion of Cenozoic Asia and the flux of clastic sediment to the ocean. Earth and Planetary Science Letters, v. 241, pp. 571-580.

Colbert, E.H., 1935, Siwalik mammals in American Museum of Natural History. Transactions of the American Philosophical Society. v. 26, 401p.

Coutand, I., Barrier, L., Govin, G., Grujic, D., Hoorn, C., DupontNivet, G., and Najman, Y., 2016, Late Miocene-Pleistocene evolution of India-Eurasia convergence partitioning between the Bhutan Himalaya and the Shillong Plateau: New evidences from foreland basin deposits along the Dungsam Chu section, eastern Bhutan: Tectonics, v. 35, pp. 2963-2994.

Deeken, A, Thiede, R.C., Sobel, E.R., Hourigan, J.K. and Strecker, M.R.,2011, Exhumational variability within the Himalaya of northwest India. Earth and Planetary Science Letters, v. 305, pp.103-114.

Flemings, P.D., and Jordan, T.E.,1990, Stratigraphy modelling of 
foreland basins: interpreting thrust deformation and lithospheric rheology. Geology, v.18,430-434.

Gavillot, Y., Meigs, A. J., Sousa, F. J., Stockli, D., Yule, D., and Malik, M., 2018, Late Cenozoic foreland-to-hinterland low-temperature exhumation history of the Kashmir Himalaya. Tectonics, 37. https://doi.org/10.1029/2017TC004668.

Ghosh, S.K., and Kumar, R., 2000, Petrography of Neogene Siwalik sandstone of the Himalayan foreland basin, Garhwal Himalaya: Implications for source area tectonics and climate. Journal Geological Society of India, v. 55, pp. 1-15.

Ghosh, S.K., Kumar, R., and Suresh, N., 2003, Influence of MioPliocene Drainage Re-organisation in the detrital modes of sandstone, Subathu sub-basin, Himalayan Foreland Basin. Himalayan Geology, v. 24, pp. 35-46.

Ghosh, P., Padia, J.T., Mohindra, R., 2004, Stable isotopic studies of paleosol sediment from Upper Siwalik of Himachal Himalaya: evidence from high monsoonal intensity during Late Miocene. Paleogeography Paleoclimatology Paleoecology, v. 206, pp. 103114.

Ghosh, S., Sanyal, P., Sangode, S.J., and Nanda, A.C., 2018, Substrate control of C4 plant abundance in the Himalayan foreland: A study based on inter-basinal records from Plio-Pleistocene Siwalik Group sediments. Palaeogeography, Palaeoclimatology, Palaeoecology, v. 511, pp.341-351.

Gilbert, C.C., Patel, B.A., Singh, N.P., Campisano, C.J., Fleagle, J.G., Rust, K.L., and Patnaik, R., 2017, New sivaladapid primate from Lower Siwalik deposits surrounding Ramnagar (Jammu and Kashmir State), India. Journal Human Evolution. v.102, pp.2141.

Goswami, P.K., and Deopa, T., 2018, Lithofacies characters and depositional processes of a Middle Miocene Lower Siwalik fluvial system of the Himalayan foreland basin, India. Journal of Asian Earth Sciences, v. 162, pp.41-53.

Govin, G., Najman, Y., Dupont-Nivet, G., Millar, I., Van Der Beek, P., Huyghe, P., Sullivan, P., Mark, C., and Vögeli, N., 2018, The tectonics and paleo-drainage of the easternmost Himalaya (Arunachal Pradesh, India) recorded in the Siwalik rocks of the foreland basin. American Journal of Science, v. 318, pp.764-798.

Jain, A. K., Kumar, D., Singh, S., Kumar, A., and Lal, N., 2000, Timing, quantification and tectonic modelling of PlioceneQuaternary movements in the NW Himalaya: Evidence from fission track dating. Earth Planetry Science Letters, v. 179, pp.437-451.

Jain, A.K., Lal, N., Sulemani, B., Awasthi, A.K., Singh, S., Kumar, R. and Kumar, D., 2009, Detrital-zircon fission-track ages from the Lower Cenozoic sediments, NW Himalayan foreland basin: Clues for exhumation and denudation of the Himalaya during the India-Asia collision. Geological Society of America Bulletin, v. 121, pp.519-535.

Johnson, G.D., Opdyke, N.D., Tandon, S.K., and Nanda, A.C., 1983, The magnetic polarity stratigraphy of the Siwalik Group at Haritalyangar (India) and a new last appearance datum for Ramapithecus and Sivapithecus in Asia. Palaeogeography, Palaeoclimatology, Palaeoecology, v. 44, pp.223-249.

Karunakaran, C., and Ranga Rao, A., 1976, Status of exploration for hydrocarbons in the Himalayan region-contributions to stratigraphy and structure. Himalayan Geology. Seminar, New Delhi. pp.1-72.

Kotla, S.S., Patnaik, R., Sehgal, R.K., and Kharya, A., 2018, Isotopic evidence for ecological and climate change in the richly fossiliferous Plio-Pleistocene Upper Siwalik deposits exposed around Chandigarh, India. Journal of Asian Earth Sciences, v. 163, pp. 32-42.

Kumar, R., 1993, Coalescence megafan: multistorey sandstone complex of the Late-Orogenic (Mio-Pliocene) sub-Himalayan belt, Dehra Dun, India. Sedimentary Geology, v. 85, pp. 327337.

Kumar, R., and Ghosh, S.K., 1991, Sedimentological studies of the Upper Siwalik Boulder Conglomerate of Mohand area, District Saharanpur, U.P. Himalayan Geology, v. 2, pp. 169-176.

Kumar, R., and Ghosh, S.K., 1994, Evolution of the Mio-Pleistocene alluvial fan system in the Siwalik Foreland Basin, Dehra Dun, India. In: Kumar, R., Ghosh, S.K., and Phadtare, N.R., (Eds.), Siwalik Foreland Basin of Himalaya. Himalayan Geology, v. 15, pp.143-159.

Kumar, R., and Nanda, A.C., 1989, Sedimentology of the Middle Siwalik sub-Group of Mohand area, Dehra Dun valley, India. Journal Geological Society of India, v. 34, pp. 597-616.

Kumar, R., and Tandon, S.K., 1985, Sedimentology of PlioPleistocene Late Orogenic deposits associated with intraplate subduction- the Upper Siwalik Subgroup of a part of Panjab SubHimalaya, India. Sedimentary Geology, v. 42, pp. 105-158.

Kumar, R., Ghosh, S.K., and Sangode, S.J., 1999, Role of thrusting in the evolution fluvial system, Himalayan Foreland Basin, India. In: Macfarlane, A., Sorkhabi,R.B., and, Quade, J., (Eds.), Himalayan and Tibet: Mountain Roots to Mountain Tops. Geological Society of America, Special. Publication, v. 328, pp. 239-256.

Kumar, R., Ghosh, S.K., Sangode, S.J., and Thakur, V.C., 2002, Manifestation of Intra-Foreland thrusting in the Neogene Himalayan foreland basin fill. Journal Geological Society of India, v. 59, pp. 547-560.

Kumar, R, Ghosh, S. K., Mazari R.K., and Sangode, S.J., 2003a, Tectonic impact on fluvial deposits of Plio- Pleistocene Himalayan foreland basin, India. Sedimentary Geology, v.158, pp. 209-234.

Kumar, R., Ghosh, S.K. and Sangode, S.J., 2003b, Mio-Pliocene sedimentation history in the northwestern part of the Himalayan foreland basin, India. Current Science, v. 84, pp. 1006-1013.

Kumar, R., Ghosh, S.K., and Sangode, S.J., 2004b, Depositional environment of Mio-Pleistocene coarse clastic facies in the Himalayan foreland basin, India. Himalayan. Geology, v. 25, pp. 101-120.

Kumar, R., Sangode, S.J., and Ghosh, S.K., 2004a, A Multistory sandstone complex of the Himalayan foreland basin, NW Himalaya, India. Journal Asian Earth Science, v. 23, pp. 407426.

Kumar, R., Suresh, N., Sangode, S. J., and Kumaravel, V., 2007, Evolution of quaternary alluvial fan system in the Himalayan foreland basin: implications to tectonic and climatic decoupling. Quaternary International, v. 159, pp. 6-20.

Kumar, R., Sangode, S. J., Ghosh, S.K., and Sinha, S., 2008, Marine to fluvial transition and erosional hiatus in the Paleogene sediments of NW Himalayan Foreland Basin, India. Himalayan Geology, v. 29, pp.147-160.

Kumaravel, V., Sangode, S. J., Siva Siddaiah, N., and Kumar, R., 2005, Rock magnetic characterization of pedogenesis under high energy depositional conditions: A case study from the MioPliocene Siwalik fluvial sequence near Dehra Dun, NW Himalaya, India. Sedimentary Geology, v.177, pp. 229-252.

Kumar, R., Ghosh, S.K., and Sangode, S.J.,2011, Sedimentary architecture of late Cenozoic Himalayan foreland basin fill: An overview. Memoir Geological Society of India, v.78, pp. 245280.

Lang, K.A., and Huntington, K.W., 2014, Antecedence of the YarlungSiang-Brahmaputra River, eastern Himalaya. Earth and Planetary Science Letters, v. 397, pp. 145-158.

Lang, K.A., Huntington, K.W., Burmester, R., and Housen, B., 2016, Rapid exhumation of the eastern Himalayan syntaxis since the 
Late Miocene: Geological Society of America Bulletin, v. 128, p. 1403-1422.

Meigs, A.J., Burbank, D.W., and Beck, R.A., 1995, Middle -Late Miocene ( $>10 \mathrm{Ma}$ ) formation of the Main Boundary thrust in the western Himalaya. Geology, v. 23, pp. 423-426.

Métivier, F., Gaudemer, Y., Tapponnier, P., and Klein, M., 1999, Mass accumulation rates in Asia during the Cenozoic. Geophysical Journal International, v. 137, pp. 280-318.

Montgomery, D.R., and Brandon, M.T., 2002, Topographic controls on erosion rates in tectonically active mountain ranges. Earth and Planetary Science Letters, v. 201, pp. 481-489.

Mugnier, J.L., and Huyghe, P., 2006, Ganges basin geometry records a pre-15 Ma isostatic rebound of Himalaya. Geology, v. 34, pp. 445-448.

Najman, Y., Johnson, K., White, N., and Olivers, G., 2004, Evolution of Himalayan foreland basin, NW India. Basin Research., v. 16, pp. 1-24.

Najman, Y., 2006, The sediment record of orogenesis: a review of approaches and techniques used in the Himalaya. Earth Science Review, v.74, pp. 1-72.

Najman, Y., Appel, E., Boudagher-Fadel, M., Bown, P., Carter, A., Garzanti, E., Godin, L., Han, J., Liebke, U., Oliver, G., Parrish, R., and Vezzoli, G., 2010, Timing of India-Asia collision: geological, biostratigraphic, and palaeomagnetic constraints. Journal Geophysical Research, Solid Earth, v.115, B12416. doi:10.1029/2010JB007673.

Nanda, A.C., 2002, Upper Siwalik mammalian faunas of India and associated events. Journal Asian Earth Science, v. 21, pp. 47-58.

Nanda, A.C., 2013, Upper Siwalik mammalian faunas of the Himalayan foothills. Journal Palaeontological Society of India, v. 58, pp.75-86.

Nanda, A.C., 2015, Siwalik Mammalian Faunas of the Himalayan Foothills: With Reference to Biochronology, Linkages and Migration. Wadia Institute of Himalayan Geology, Dehradun, Monograph 2, $341 \mathrm{p}$.

Nanda, A.C., and Sehgal, R.K., 1993, Siwalik mammalian faunas from Ramnagar (J. \& K.) and Nurpur (H.P.) and lower limit of hipparion. Journal Geological Society of India, v. 42, pp.115134.

Nanda A.C., Sehgal, R.K., and. Chauhan, P.R., 2018, Siwalik-age faunas from the Himalayan Foreland Basin of South Asia. Journal of Asian Earth Sciences, v.162, pp.54-68.

Pilgrim, G.E., 1913, The correlation of the Siwaliks with the mammalian horizons of Europe. Records Geological Survey of India, v. 43, pp. 264- 325.

Parkash, B., Sharma, R.P., and Roy, A.K., 1980, The Siwalik Group (molasse) sediments shed by collision of continental plates. Sedimentary Geology, v. 25, pp. 127- 159.

Patnaik, R., 2013, Indian Neogene Siwalik mammalian biostratigraphy: An overview. In: Wang, X., Flynn, L.J., and Fortelius, M., (Eds.), Fossil Mammals of Asia: Neogene Biostratigraphy and Chronology. Columbia University Press, New York, pp. 423-444.

Quinlan, G.M., and Beaumont, C.,1984, Appalachian thrusting, lithospheric flexure, and the Paleozoic stratigraphy of theeastern interior of North America. Canadian Journal of Earth Science, v. 21, pp. 973-996.

Raiverman, V., and Raman, K.S., 1971, Facies relations in the Subathu sediments, Simla Hills, N.W. Himalaya, India. Geological Magzine, v.108, pp. 329-341.

Raiverman, V., Kunte, S.V., and Mukherjee, A., 1983, Basin geometry, Cenozoic sedimentation and hydrocarbon prospects in northwestern Himalaya and Indo-Gangetic plains. Petroleum Asia Journal, v. 6, pp. 67-92.
Raiverman, V. 2002. Foreland Sedimentation in Himalayan Tectonic Regime - A relook at the orogenic process, Bisen Singh Mahendra Pal Singh, Dehra Dun, India, 371p.

Ranga Rao, A.,1993, Magnetic Polarity Stratigraphy of Upper Siwalik of North Western Himalayan Foothills. Current Science, v.64, pp. 863-873.

Ranga Rao, A., Nanda, A.C., Sharma, U.N., and Bhalla, M.S., 1995, Magnetic polarity stratigraphy of the Pinjor Formation (Upper Siwalik) near Pinjore, Haryana. Current Science, v.68, pp. 12311236.

Sahni, A., Tiwari, B.N., and Kumar, K., 1983, A report on the occurrence of Ramapithecus punjabicus (Hominoidea) from the Uttar Pradesh Siwaliks. Himalayan Geology, v. 11, pp.193-197.

Sangode, S.J., 2014, Magnetostratigraphic perspectives on MioPliocene sedimentation in the Himalayan foreland and Bengal Basin. Palaeontological Society of India, Special Publication. No. 5, pp. 65-86.

Sangode, S.J., and Kumar R., 2003, Magnetostratigraphic correlation of the Late Cenozoic fluvial sequences from NW Himalaya, India. Current Science, v. 84, pp. 1014-1024.

Sangode, S. J., Kumar, R., and Ghosh, S. K., 1999, Palaeomagnetic and rock magnetic perspectives on the post-collision continental sediments of the Himalaya, India. In: Radhakrishna, T., and Piper, J.D.A., (Eds.), The Indian subcontinent and Gondwana: a palaeomagnetic and rock magnetic perspective. Memoir Geological Society of India, v.44, pp. 221-248.

Sangode, S.J., Kumar, R., and Ghosh, S.K., 2003, Magnetic polarity study of the late Miocene Siwalik Group sediments from Kangra re-entrant, HP, India. Himalayan Geology, v. 24, pp. 47-61.

Sangode, S.J., Kumar, R., and Ghosh, S.K., 1996, Magnetic polarity stratigraphy of the Siwalik sequence of Haripur (H.P.), NW Himalaya. Journal Geological Society of India, v. 47, pp.683704.

Sangode, S.J., Kumar, R.,Ghosh, S.K.,and Badekar, A.G., 2010, Magnetic stratigraphy across a Late Paleocene-Eocene Marine to continental transition sequence of the Subathu and Dagshai Formation in the NW Himalaya, India. Gondwana Geological Magazine, v. 25, 227-235.

Sanyal, P., Bhattacharya, S.K., Kumar, R., Ghosh, S.K., and Sangode, S.J., 2004, Mio-Pliocene monsoonal record from Himalayan foreland basin (Indian Siwalik) and its relation to vegetational change. Palaeogeography, Palaeoclimatology, Palaeoecology, v. 205, pp. 23-41.

Sanyal, P, Sarkar, A., Bhattacharya, S.K., Kumar, R., Ghosh, S.K., and Agarwal, S., 2010, Intensification of monsoon, microclimate and asynchronous C4 appearance: isotopic evidence from the Indian Siwalik sediments. Palaeogeography, Palaeoclimatology, Palaeoecology, v. 296, pp.165-173.

Schumm, S. A., and Rea, D.K., 1995, Sediment yield from disturbed earth systems. Geology, v. 23, pp. 391-394.

Sen, D.P., 1981, Early Tertiary deltaic sedimentation around Kalka and Nahan, Punjab Himalaya, India. Sedimentary Geology, v.30, pp.291-310.

Sinclair, H.D., Coakley, B.J., Allen, P.A., and Watts, A.B., 1991, Simulation of foreland basin stratigraphy using a diffusion model mountain belt uplift and erosion; an example from the Central Alps, Switzerland. Tectonics, v. 10, pp. 599-620.

Singh, B.P., Tandon, S.K., Singh, G.P., and. Pawar, J.S., 2009, Palaeosols in early Himalayan foreland basin sequences demonstrate latitudinal shift-related long-term climatic change. Sedimentology, v. 56, pp.1464-1487.

Singh, I.B., 1978, On some sedimentological and palaeoecological aspects of the Subathu-Dagshai-Kasauli succession of Simla Hill. Journal Palaeontological Society of India, v. 21, pp. 19-28. 
Sinha, S., Sangode, S.J., Kumar, R., and Ghosh S.K., 2005, Accumulation history and tectonic significance of the Neogene continental deposits in the west central sector of the Himalayan foreland basin. Himalayan Geology, v. 26, pp. 287-308.

Sinha, S., Kumar, R., Ghosh, S.K., and Sangode, S.J., 2007, Controls on expansion-contraction of late Cenozoic alluvial architecture: A case study from the Himalayan Foreland Basin, NW Himalaya, India. Himalayan Geology, v. 28, pp. 1-22.

Sinha, S., Ghosh, S. K., Kumar, R., Islam, R., Sanyal, P., and Sangode, S. J., 2008, Role of Tectono-Climatic Factors in the Neogene Himalayan Foreland Sediments: Petrology and Geochemical Approach, Kangra Sub-basin. Journal Geological Society of India, v. 71, pp. 787-807.

Sinha S, Sen, K., Sangode, S. J., Kumar, R., and Ghosh S. K., 2009, Sedimentology and AMS studies along a part of the Siwalik Foreland Basin: Implications for tectono-sedimentary expression, Nurpur Salient, NW Himalaya, India. Current Science, v.96, pp.260-267.

Srivastava, V.K., and Casshyap, S.M., 1983, Evolution of the PreSiwalik Tertiary basin of Himachal Himalaya. Journal Geological Society of India, v.24, pp. 134-147.

Suresh, N., Ghosh, S.K., Kumar, R., and Sangode, S.J., 2004, Claymineral distribution patterns in late Neogene fluvial sediments of the Subathu sub-basin, central sector of Himalayan foreland basin: implications for provenance and climate. Sedimentary Geology, v. 163 , pp. 265-278.

Tandon, S.K.,1976, Siwalik sedimentation in a part of Kumaon Himalaya, India. Sedimentary Geology, v. 16: pp.131-154.

Tandon, S.K., 1991, The Himalayan Foreland: focus on Siwalik Basin. In: Tandon, S.K., Pant,C.C., and Casshyap,S.M., (Eds.), Sedimentary Basins of India: Tectonic Context. Gyanodaya Prakashan, Nainital (India), pp. 177-201.

Tandon, S.K., Kumar, R., Koyama, M., and Niitsuma, N., 1984, Magnetic polarity stratigraphy of the Upper Siwalik Subgroup, east of Chandigarh, Punjab Sub-Himalaya, India. Journal
Geological Society of India, v. 25, pp. 45-55.

Tandon, S.K., and Rangaraj, S., 1979, Sedimentary tectonics of the Siwalik sequence, southeast of the Ravi structural re-entrant. In: Saklani, P.S., (Ed.), Structural geology of the Himalaya. Today and Tomorrow's Printers and Publishers, New Delhi, pp.273282.

Tandon, S.K., and Kumar, R., 1984, Active intra-basinal highs and palaeodrainage reversals in the late orogenic hominid-bearing Siwalik basin. Nature, v. 308, pp. 635-637.

Thiede, R., Robert, X., Stübner, K., Dey, S., and Faruhn, J., 2017, Sustained out-of-sequence shortening along a tectonically active segment of the Main Boundary thrust: The Dhauladhar Range in the northwestern Himalaya. Lithosphere; v. 9, pp. 715-725.

van Hinsbergena, D.J.J., Lippertc, P.C., Dupont-Nivete, G., McQuarrieh, N., Doubrovinea, P. V., Spakmani, W., and Torsvik, T. H., 2012, Greater India Basin hypothesis and a two-stage Cenozoic collision between India and Asia. Proceedings of the National Academy of Sciences of the United States of America, v. 109, pp.7659-7664.

Vögeli, N., Najman, Y., van der Beek, P., Huyghe, P., Wynn, P., Govin, G., Van Der Veen, I., and Sachse, D., 2017, Lateral variations in vegetation in the Himalaya since the Miocene and implications for climate evolution. Earth Planetary Science Letters, v. 471, pp. 1-9.

White, N.M., Pringle, M., Garzanti, E., Bickle, M., Najman, Y., Chapman, H., and Friend, P., 2002, Constraints on the exhumation and erosion of the High Himalayan Slab, NW India, from foreland basin deposits. Earth and Planetary Science Letters, v. 195, pp. 29-44.

Willis, B., 1993, Ancient river systems in the Himalayan Foredeep, Chinji village area, northern Pakistan. Sedimentary Geology, v. 88, pp. 1-76.

Wobus C., Heimsath A., Whipple K., and Hodges, K.V., 2005, Active out-of-sequence thrust faulting in the central Nepalese Himalaya. Nature, v. 434, pp. 1008-1011.

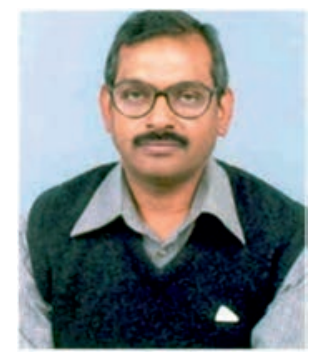

Dr Rhotash Kumar has worked extensively on the Neogene and Quaternary fluvial successions of the Foreland basin of Himalaya. He has also studied the Ladakh molasses, Spiti Basin and geological formations of Karakoram area. 